\title{
Serum concentrations of brain-derived neurotrophic factor in patients diagnosed with gender dysphoria undergoing sex reassignment surgery
}

\author{
Concentração sérica de fator neurotrófico derivado do cérebro em pacientes \\ diagnosticados com disforia de gênero que realizaram cirurgia de redesignação sexual
}

\author{
Maiko A. Schneider, ${ }^{1}$ Tahiana Andreazza, ${ }^{1}$ Anna Martha V. Fontanari, ${ }^{1,2}$ Angelo B. Costa ${ }^{1}$ Dhiordan C. da Silva, ${ }^{1}$ \\ Bianca W. de Aguiar, ${ }^{2}$ Raffael Massuda, ${ }^{2}$ Mariana Pedrini, ${ }^{2}$ Clarissa S. Gama, ${ }^{1,2}$ Karine Schwarz, ${ }^{1}$ \\ Marcia Kauer-Sant'Anna, ${ }^{2}$ Maria Ines R. Lobato, ${ }^{1,2}$
}

\begin{abstract}
Introduction: Transsexualism (ICD-10) is a condition characterized by a strong and persistent dissociation with one's assigned gender. Sex reassignment surgery (SRS) and hormone therapy provide a means of allowing transsexual individuals to feel more congruent with their gender and have played a major role in treatment over the past 70 years. Brain-derived neurotrophic factor (BDNF) appears to play a key role in recovery from acute surgical trauma and environmentally mediated vulnerability to psychopathology. We hypothesize that BDNF may be a biomarker of alleviation of gender incongruence suffering.

Objectives: To measure preoperative and postoperative serum BDNF levels in transsexual individuals as a biomarker of alleviation of stress related to gender incongruence after SRS.

Methods: Thirty-two male-to-female transsexual people who underwent both surgery and hormonal treatment were selected from our initial sample. BDNF serum levels were assessed before and after SRS with sandwich enzyme linked immunosorbent assay (ELISA). The time elapsed between the pre-SRS and post-SRS blood collections was also measured.

Results: No significant difference was found in pre-SRS or post-SRS BDNF levels or with relation to the time elapsed after SRS when BDNF levels were measured.

Conclusion: Alleviation of the suffering related to gender incongruence after SRS cannot be assessed by BDNF alone. Surgical solutions may not provide a quick fix for psychological distress associated with transsexualism and SRS may serve as one step toward, rather than as the conclusion of, construction of a person's gender identity.
\end{abstract}

Keywords: Transsexualism, sex reassignment surgery, BDNF.

\section{Resumo}

Introdução: O transexualismo (CID-10) é uma condição caracterizada por forte e persistente dissociação com o gênero atribuído. A cirurgia de redesignação sexual (CRS) e a terapia hormonal (TH) permitem que indivíduos transexuais se sintam mais congruentes com seu gênero e, por isso, têm desempenhado papel importante nos últimos 70 anos. O fator neurotrófico derivado do cérebro (BDNF) parece desempenhar um papel fundamental na recuperação do trauma cirúrgico agudo e vulnerabilidade ambiental à psicopatologia. Nós hipotetizamos que o BDNF pode ser um biomarcador de alívio do sofrimento de incongruência de gênero pós-CRS.

Objetivos: Mensurar os níveis séricos de BDNF no pré e pós-operatório em indivíduos transexuais como biomarcador de alívio de estresse relacionado à incongruência de gênero após a CRS.

Métodos: Trinta e duas pessoas transexuais masculino para feminino submetidas a cirurgia e tratamento hormonal foram selecionadas de nossa amostra inicial. O nível sérico de BDNF foi avaliado antes e depois da CRS pela técnica ELISA. O tempo decorrido entre as coletas de sangue pré e pós-CRS foi medido.

Resultados: Não houve diferença significativa nos níveis de BDNF pré e pós-CRS ou em relação ao tempo decorrido entre a CRS e a coleta.

Conclusão: $O$ alívio do sofrimento relacionado à incongruência de gênero pós-CRS não pode ser avaliado apenas pelo BDNF. Soluções cirúrgicas podem não fornecer uma solução rápida para o sofrimento associado ao transexualismo, e a CRS pode servir como um passo em direção à, em vez de conclusão da, construção da identidade de gênero de uma pessoa.

Descritores: Transexualismo, cirurgia de redesignação sexual, BDNF.

\footnotetext{
${ }_{1}$ Programa de Identidade de Gênero (Protig), Hospital de Clinicas de Porto Alegre (HCPA), Universidade Federal do Rio Grande do Sul (UFRGS), Porto Alegre, RS, Brazil. 2 Laboratório de Psiquiatria Molecular, Instituto Nacional de Ciência e Tecnologia Translacional em Medicina (INCT-TM), Hospital de Clinicas de Porto Alegre (HCPA), Universidade Federal do Rio Grande do Sul (UFRGS), Porto Alegre, RS, Brazil.

Financial support: Conselho Nacional de Desenvolvimento Científico e Tecnológico (CNPq).

Submitted May 25 2016, accepted for publication Nov 28 2016. No conflicts of interest declared concerning the publication of this article.

Suggested citation: Schneider MA, Andreazza T, Fontanari AM, Costa AB, da Silva DC, de Aguiar BW, et al. Serum concentrations of brain-derived neurotrophic factor in patients diagnosed with gender dysphoria undergoing sex reassignment surgery. Trends Psychiatry Psychother. 2017;39(1):43-47. http://dx.doi. org/10.1590/2237-6089-2016-0033
} 


\section{Introduction}

Transsexualism (International Classification of Diseases, version 10 [ICD-10]) is a condition characterized by a strong and persistent dissociation with one's assigned gender. ${ }^{1}$ This experience is psychologically taxing and is compounded by distress caused by social stigmatization. ${ }^{2}$ Furthermore, transsexual individuals report a high prevalence of childhood trauma, with particularly high rates of emotional abuse and negligence. Sex reassignment surgery (SRS) and hormone therapy provide a means of allowing transsexual individuals to feel more congruent with their gender, and have played a major role in treatment over the past 70 years. ${ }^{1-6}$

Brain-derived neurotrophic factor (BDNF) is a member of the growth factor family that is involved in promoting synaptic plasticity, including neurogenesis, neuronal survival, and the normal maturation of neuronal developmental pathways. ${ }^{7-9}$ Low BDNF levels are a biomarker for a range of neuropsychiatric disorders, such as advanced bipolar disease, ${ }^{10}$ major depressive episodes ${ }^{11}$ and schizophrenia. ${ }^{12}$ BDNF levels increase in response to antidepressant, lithium, and valproate treatments. ${ }^{8}$

BDNF has also been linked to several recovery situations. While low BDNF levels have been associated with substance abuse disorder, increased levels of brain-derived neurotrophin were found during abstinence in substance abuse disorders, e.g., alcohol withdrawal, ${ }^{13}$ likely signaling neuronal recovery. Additionally, high levels of BDNF have been associated with craving in opiate-dependent patients, signaling a possible maladaptive plasticity associated with drug-seeking behavior during abstinence, ${ }^{14}$ and $a$ similar pattern has been observed in patients with cocaine dependence, possibly predicting cocaine abuse relapse. ${ }^{15}$

Extensive research has been conducted over the past two decades focusing on the means by which BDNF modulates neuroplasticity. For example, in 1995 Korte et al. ${ }^{16}$ showed that BDNF is predominantly synthesized by neurons and Bergami et al., ${ }^{17}$ showed that astrocytes play the role of storing and secreting BDNF. Moreover, glia have been found to utilize BDNF in neuroinflammatory and neuroprogressive processes, ${ }^{18}$ such as neuronal lesions ${ }^{19}$ and inflammatory conditions. ${ }^{20}$

The way in which hormone therapy in transsexuals may alter BDNF levels has proven a controversial subject. Fuss et al. ${ }^{21}$ conducted a study comparing transsexual females with controls and found no differences in BDNF levels after estrogen therapy, Fontanari et al., ${ }^{22}$ supposed that the low BDNF levels they found in transsexual individuals could be related to emotional trauma in childhood, while Kauer et al., ${ }^{23}$ found that low BDNF levels - as detected, for example, in bipolar individuals - were associated with traumatic life events.
The aim of our study was to explore whether BDNF levels before and after SRS correlate with recovery from psychological distress in transsexual individuals, as they correlate with recovery from distress in other disorders, such as posttraumatic stress disorder (PTSD), acute trauma, and major depression. Although several studies have evaluated psychological recovery using subjective tools, no studies have evaluated the potential of a biological marker as an objective tool for assessing postSRS alleviation of transsexual suffering.

\section{Materials and methods}

\section{Participants and procedures}

In this prospective cohort study, male-to-female transsexual people were recruited between February 2009 and December 2015 and monitored after SRS. All patients underwent classic penile inversion vaginoplasty, the surgical gold standard for male-to-female reassignment. All operations were performed by a single surgeon with many years of experience in this technique.

The inclusion criteria were as follows: diagnosis of transsexualism (ICD-10) established by a psychiatrist, age greater than 18 years, and a post-SRS period of at least 6 months. We have chosen to use the term transsexualism based on ICD-10 criteria; however, we are aware of current nomenclature changes. Patients suffering from axis I psychotic disorders, mental retardation, or substance addiction were excluded from the study. Although the Diagnostic and Statistical Manual of Mental Disorders, 4th edition (DSM-IV) diagnostic criteria are now no longer used, data collection was carried out between 2008 and 2015, when these criteria were still current, and the Mini International Neuropsychiatric Interview (MINI 6.0) is in accordance with the Diagnostic and Statistical Manual of Mental Disorders, 4th edition, text revision (DSM-IV-TR). All patients signed an informed consent form for the study, which was approved by the Research Ethics Committee (CEP HCPA No 08-167).

During this period, we evaluated 84 new patients in the clinic. Of these patients, 65 fully fit the surgical criteria and underwent SRS; 33 of these 65 patients were excluded from the analysis due to a lack of data or because they did not meet the inclusion criteria. The final sample contained 32 individuals. All male-to-female transsexuals who underwent both surgery and hormone treatment during this period were selected for the study. Figure 1 illustrates the process of exclusion or inclusion of participants who attended the initial evaluation. 


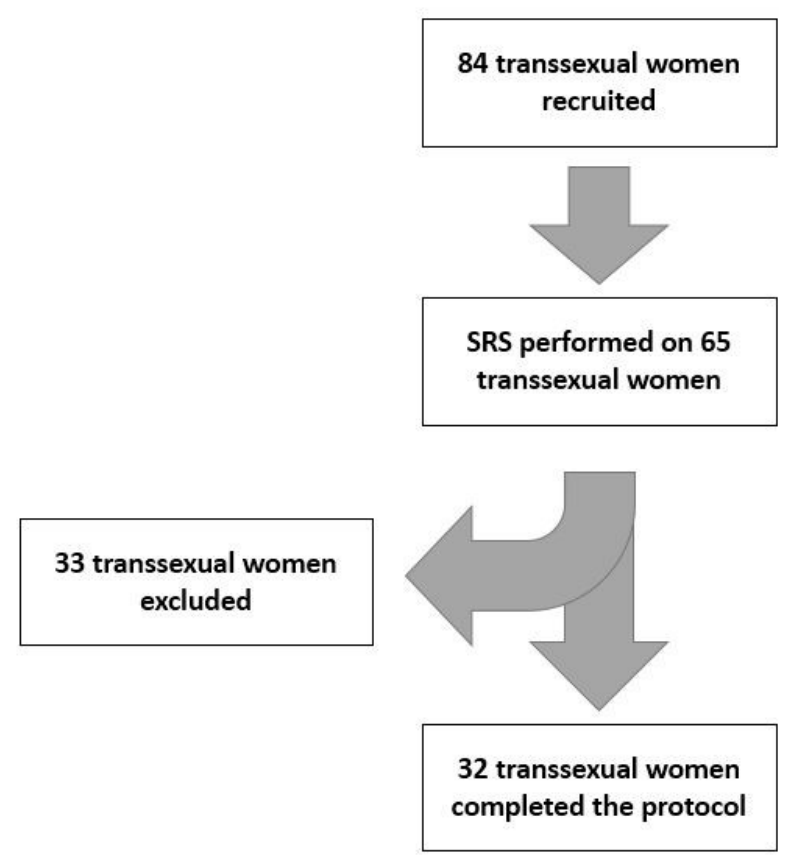

Figure 1 - Diagram of loss and/or exclusion of patients.

\section{Main outcome measures}

Five $\mathrm{mL}$ of peripheral blood were taken from each subject by venipuncture into an anti-coagulant-free vacuum tube. The blood was centrifuged at $4000 \mathrm{x}$ $\mathrm{g}$ for $10 \mathrm{~min}$, and the serum was frozen at $-80{ }^{\circ} \mathrm{C}$ until assayed. Tests were conducted with sandwich enzyme linked immunosorbent assay (ELISA), according to the manufacturer's specifications (Chemicon, USA). In short, 96-well flat-bottom microtiter plates were filled with the samples (diluted 1:2 in sample diluents) and left for a 24-hour period. The standard curve ranged from 7.8 to $500 \mathrm{pg}$ of BDNF. Plates were then washed four times with wash buffer, monoclonal anti-BDNF rabbit antibody (diluted $1: 1000$ with sample diluents) was added, and then plates were incubated for three hours at room temperature. After washing, a second incubation with anti-rabbit antibody peroxidase conjugate (diluted $1: 1000$ ) was carried out for one hour at room temperature. Next, streptavidin-enzyme, substrate, and stop solution were added, and the amount of BDNF was measured (absorbance set at $450 \mathrm{~nm}$ ). The standard curve demonstrated a direct relationship between optical density and BDNF concentration. Total protein was measured using Lowry's method, using bovine serum albumin as a standard.

Analysis was performed using the Statistical Package for the Social Sciences (SPSS) version 18.0. Most BDNF value fits were normally distributed and were therefore subjected to parametric analyses. Two-sided paired t test analyses were conducted to compare BDNF measures, significant at $p<0.05$. Data were presented as the mean \pm standard deviation. Pearson correlations were used to analyze the relationship between the time of blood collection, in days after SRS, and BDNF levels.

\section{Results}

The mean age of transsexual patients was 28.75 \pm 6.53 . BDNF serum levels were measured $279.28 \pm 190.34$ days after male-to-female SRS. The interval between the first and the second blood sample collections was $847 \pm 797.09$ days. Mean serum BDNF levels were 18.55 \pm 5.99 and $17.83 \pm 6.47$, pre-SRS and post-SRS respectively. There was no difference between pre-SRS and post-SRS BDNF levels: $\Delta=-0.73$, median difference $=-1.36 \mathrm{t} 32=0.67, \mathrm{p}=0.50$, $95 \%$ confidence interval $=-1.46$ to 2.92 (Figure 2 ). There was no significant correlation between the time of blood collection after SRS and post-SRS BDNF levels ( $r=-0.11$, $p=0.54$ ) or between the time between the pre-SRS and post-SRS blood collections and post-SRS BDNF levels ( $r=$ -0.05, $p=77$ ).

Fifteen HIV+ subjects were included in the sample. These patients were included in the final analysis because we were comparing the same cases before and after SRS and so this confounding factor affected the two data collection times equally.
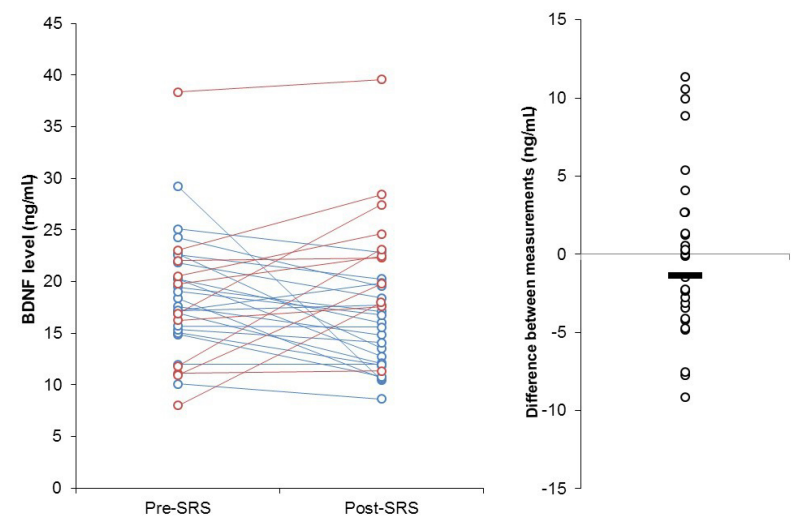

Figure 2 - Brain-derived neurotrophic factor (BDNF) levels before and after sex reassignment surgery (SRS) and differences between them.

\section{Discussion}

BDNF has been identified as a possible predictor of treatment response in some types of psychiatric distress. ${ }^{24}$ There is also evidence to suggest that patients remain 
satisfied after SRS and that it alleviates the suffering caused by living in non-conformity with their gender identity. ${ }^{25-27}$ In alignment with this extant research, this study posited that alleviation of this suffering after SRS would be traceable through BDNF serum levels.

However, contrary to this hypothesis, the difference between preoperative and postoperative BDNF levels was not significant. One way to interpret these findings is to consider that SRS could serve as one step toward, rather than the conclusion of, a person's gender identity construction and so the molecular response may require extensive recuperation, not occurring immediately after SRS. This interpretation can be sustained considering that SRS cannot reverse the effects of the chronic psychological trauma associated with transsexuals' life experiences, at least not in the short term or as an isolated intervention.

Another important point to consider is the effect on BDNF levels of the neuroactive steroids used by patients. All of our participants were undergoing hormonal sex reassignment therapy. A myriad of in vitro studies have evaluated the type of neuronal effects exerted by the steroids we currently use in the reassignment process. Estradiol and progesterone have been shown to directly and indirectly increase neuroplasticity, via BDNF augmentation and glutamate respectively. ${ }^{28}$ These in vitro models have demonstrated that steroidal hormones augment release of BDNF from neurons or astrocytes. ${ }^{29}$

Notably, Fuss et al., ${ }^{21}$ found a negative correlation between estradiol treatment during the reassignment process and BDNF levels in their group of transsexual women. Their finding was somewhat surprising, because earlier studies had found the opposite. There is a correlation between the menses cycle and brain neurotrophin secretion, for example, with positive BDNF fluctuation in response to estradiol ${ }^{30}$ at the end of the follicular phase. On one hand, we expect elevation of BDNF levels after SRS - consistent with other psychiatric models of suffering alleviation (anxiety, major depression, bipolar disease, schizophrenia, and PTSD) - but on the other hand, we have information that BDNF levels diminish with estradiol treatment. We can therefore hypothesize that the effects of these interventions are opposite and neutralizing when conjugated. Any augmentation of BDNF due to alleviation of distress would be neutralized by the negative effects of estradiol on BDNF in transsexuals.

Nevertheless, studying transsexuals may be subject to certain peculiarities compared with studying nontranssexual individuals. The majority of neurobiological models of neuroactive steroids are tested in nontranssexual individuals or in animals. The significance of this must be considered. There are indications that transsexual individuals respond differently to steroids than cissexuals do. For a long period of time, it was believed that the brain would be dimorphic in some aspects for men and women, with a type of intermediate variation of some structures for transsexuals, ${ }^{31}$ and estrogen exerts an effect on neuronal development. ${ }^{32}$ Although new evidence of brain morphology and functional magnetic resonance imaging contest the idea of macroscopic dimorphisms across gender, ${ }^{33}$ we do not know exactly what happens microscopically in treatment with estradiol, an XY chromosome: Molecular responses might be "dimorphic." There may be microscopic - beyond molecular - properties intrinsic to the sexual chromatin that dictate different responses between transsexual and non-transsexual individuals, e.g., the second messenger machinery and the neurokinin system.

Increasing sample sizes to ensure that there BDNF serum levels are truly non-significant biologically, and not a result of our meager participant pool, would be advisable for forthcoming research.

\section{Conclusion}

Although this particular study has proven nonsignificant, it has provided a critical inference: surgical solutions may not provide a quick fix for psychological distress associated with transsexualism. Although BDNF levels may be able to recover rapidly from acute trauma, it appears that transsexualism may require more extensive rehabilitation, in accordance with the hypothesis that the early and continual neurological effects of prejudice that transsexual patients suffer throughout their lives could be observed as continuous trauma that influences neuroplasticity, resulting from social vulnerability. 34,35 These results have opened up avenues for more comprehensive research opportunities that could evaluate the association of BDNF levels in transsexualism. While ensuing studies will need to readdress confounding factors in this methodology, these results should allow for a more extensive and informed support system for medical interventions in transsexual individuals.

\section{Acknowledgements}

This study was supported by Conselho Nacional de Desenvolvimento Científico e Tecnológico (CNPq).

\section{References}

1. Coleman E, Bockting W, Botzer M, Cohen-Kettenis P, DeCuypere G, Feldman J, et al. Standards of care (SOC) for the health of 
transsexual, transgender, and gender-nonconforming people, version 7. Int J Transgend. 2012;13:165-232.

2. Hoshiai M, Matsumoto Y, Sato T, Ohnishi M, Okabe N, Kishimoto Y, et al. Psychiatric comorbidity among patients with gender identity disorder. Psychiatry Clin Neurosci. 2010;64:514-9.

3. Dhejne $C$, Lichtenstein $P$, Boman $M$, Johansson $A L$, Långström $N$, Landén M. Long-term follow-up of transsexual persons undergoing sex reassignment surgery: cohort study in Sweden. PLoS One. 2011;6:e16885.

4. Kuhn A, Bodmer C, Stadlmayr W, Kuhn P, Mueller MD, Birkhäuser, M. Quality of life 15 years after sex reassignment surgery for transsexualism. Fertil Steril. 2009;92:1683-9.

5. Lobato MI, Koff WJ, Manenti C, da Fonseca Seger D, Salvador J, da Graça Borges Fortes M, et al. Follow-up of sex reassignment surgery in transsexuals: a Brazilian cohort. Arch Sex Behav. 2006;35:711-5.

6. Matsumoto $Y$, Sato T, Ohnishi M, Kishimoto $Y$, Terada S, Kuroda S. Stress-coping strategies of patients with gender identity disorder. Psychiatry Clin Neurosci. 2009;63:715-20.

7. Fernandes BS, Gama CS, Kauer-Sant'Anna M, Lobato MI, Belmontede-Abreu P, Kapczinski F. Serum brain-derived neurotrophic factor in bipolar and unipolar depression: a potential adjunctive tool for differential diagnosis. J Psychiatr Res. 2009;43:1200-4.

8. Grande I, Fries GR, Kunz M, Kapczinski F. The role of BDNF as a mediator of neuroplasticity in bipolar disorder. Psychiatry Investig. 2010;7:243-50.

9. Smith MA, Makino S, Kvetnansky R, Post RM. Stress and glucocorticoids affect the expression of brain-derived neurotrophic factor and neurotrophin-3 mRNAs in the hippocampus. J Neurosci. 1995:15:1768-77.

10. Shaltiel G, Chen G, Manji HK. Neurotrophic signaling cascades in the pathophysiology and treatment of bipolar disorder. Curr Opin Pharmacol. 2007;7:22-6.

11. Schmidt HD, Banasr M, Duman RS. Future antidepressant targets: neurotrophic factors and related signaling cascades. Drug Discov Today Ther Strateg. 2008;5:151-6.

12. Egan MF, Kojima M, Callicott JH, Goldberg TE, Kolachana BS, Bertolino $A$, et al. The BDNF val66met polymorphism affects activity-dependent secretion of BDNF and human memory and hippocampal function. Cell. 2003;112:257-69.

13. Köhler S, Klimke S, Hellweg R, Lang UE. Serum brain-derived neurotrophic factor and nerve growth factor concentrations change after alcohol withdrawal: preliminary data of a case-control comparison. Eur Addict Res. 2013;19:98-104.

14. Heberlein $A$, Dürsteler-MacFarland KM, Lenz $B$, Frieling $H$, Grösch M, Bönsch D, et al. Serum levels of BDNF are associated with craving in opiate-dependent patients. J Psychopharmacol. 2011;25:1480-4.

15. D'Sa C, Fox HC, Hong AK, Dileone RJ, Sinha R. Increased serum brain-derived neurotrophic factor is predictive of cocaine relapse outcomes: a prospective study. Biol Psychiatry. 2011;70:706-11.

16. Korte $M$, Carroll P, Wolf E, Brem G, Thoenen $H$, Bonhoeffer T. Hippocampal long-term potentiation is impaired in mice lacking brain-derived neurotrophic factor. Proc Natl Acad Sci U S A. 1995; $92: 8856-60$.

17. Bergami M, Santi S, Formaggio E, Cagnoli C, Verderio C, Blum R, et al. Uptake and recycling of pro-BDNF for transmitter-induced secretion by cortical astrocytes. J Cell Biol. 2008;183:213-21.

18. Kato TA, Hayakawa K, Monji A, Kanba S. Missing and possible link between neuroendocrine factors, neuropsychiatric disorders, and microglia. Front Integr Neurosci. 2013;7:53.

19. Rudge JS, Pasnikowski EM, Holst P, Lindsay RM. Changes in neurotrophic factor expression and receptor activation following exposure of hippocampal neuron/astrocyte cocultures to kainic acid. J Neurosci. 1995;15:6856-67.

20. Giralt A, Friedman HC, Caneda-Ferron B, Urban N, Moreno E, Rubio N, et al. BDNF regulation under GFAP promoter provides engineered astrocytes as a new approach for long-term protection in Huntington's disease. Gene Ther. 2010;17:1294-308.
21. Fuss J, Hellweg R, Van Caenegem E, Briken P, Stalla G, T'Sjoen G, et al. Cross-sex hormone treatment in male-to-female transsexual persons reduces serum brain-derived neurotrophic factor (BDNF). Eur Neuropsychopharmacol. 2014;25:95-9.

22. Fontanari AM, Andreazza $T$, Costa $A B$, Salvador J, Koff WJ, Aguiar B. Serum concentrations of brain-derived neurotrophic factor in patients with gender identity disorder. J Psychiatr Res. 2013;47:1546-8.

23. Kauer-Sant'Anna M, Tramontina J, Andreazza AC, Cereser K, da Costa S, Santin A, et al. Traumatic life events in bipolar disorder: impact on BDNF levels and psychopathology. Bipolar Disord. 2007;9:128-35.

24. Fernandes BS, Massuda R, Torres M, Camargo D, Fries GR, Gama $\mathrm{CS}$, et al. Improvement of schizophrenia with electroconvulsive therapy and serum brain-derived neurotrophic factor levels: lack of association in a pilot study. Psychiatry Clin Neurosci. 2010;64:6635 .

25. Murad MH, Elamin MB, Garcia MZ, Mullan RJ, Murad A, Erwin PJ, et al. Hormonal therapy and sex reassignment: a systematic review and meta-analysis of quality of life and psychosocial outcomes. Clin Endocrinol (Oxf). 2010;72:214-31.

26. Rehman J, Melman A. Formation of neoclitoris from glans penis by reduction glansplasty with preservation of neurovascular bundle in male-to-female gender surgery: functional and cosmetic outcome. J Urol. 1999;161:200-6.

27. Salvador J, Massuda R, Andreazza T, Koff WJ, Silveira E, Kreische $\mathrm{F}$, et al. Minimum 2-year follow up of sex reassignment surgery in Brazilian male-to-female transsexuals. Psychiatry Clin Neurosci. 2012;66:371-2.

28. Baudry $\mathrm{M}, \mathrm{Bi} X$, Aguirre $\mathrm{C}$. Progesterone-estrogen interactions in synaptic plasticity and neuroprotection. Neuroscience. 2013;239:280-94.

29. García-Ovejero D, Veiga S, García-Segura LM, Doncarlos LL. Glia expression of estrogen and androgen receptors after rat brain injury. J Comp Neurol. 2002;450:256-71.

30. Cubeddu A, Bucci F, Giannini A, Russo M, Daino D, Russo N, et al. Brain-derived neurotrophic factor plasma variation during the different phases of the menstrual cycle in women with premenstrual syndrome. Psychoneuroendocrinology. 2011;36:523-30.

31. Savic I. Asymmetry of cerebral gray and White matter and structural volumes in relation to sex hormones and chromosomes. Front. Neurosci. 2014;8:329.

32. Hines M. Early androgen influences on human neural and behavioral development. Early Hum Dev. 2008;84:805-7.

33. Joel D, Berman Z, Tavor I, Wexler N, Gaber O, Stein Y, et al. Sex beyond the genitalia: the human brain mosaic. Proc Natl Acad Sci U S A. 2015;112:15468-73.

34. Costa AB, Fontanari AM, Andreazza T, Salvador J, Koff WJ, Aguiar $B$, et al. BDNF: a biomarker for social vulnerability in individuals diagnosed with gender dysphoria. J Psychiatr Res. 2014;50:16-7.

35. Fontanari AM, Costa AB, Aguiar B, Tusset $C$, Andreazza $T$, Schneider $M$, et al. Reduced serum concentrations of brain-derived neurotrophic factor (BDNF) in transsexual Brazilian men. Neurosci Lett. 2016;630:109-13.

\section{Correspondence:}

Maiko A. Schneide

Universidade Federal do Rio Grande do Sul

Hospital de Clínicas de Porto Alegre, Psiquiatria Forense

Rua Ramiro Barcellos, 2350

90035-903 - Porto Alegre, RS - Brazil

Tel.: + 55 (51) 9772.2606 / + 55 (51) 3359.8000

E-mail: maikoschneider@hcpa.edu.br 